\title{
Tokat Artova Çelikli Gölet Havzasında Toprak Bozulmasının Yersel ve Zamansal Değişiminin Belirlenmesi
}

\author{
Bülent Orkun İNAÇ ${ }^{1}$ İrfan OĞUZ²*, Rasim KOÇYİĞİT² \\ ${ }^{1}$ İlçe Tarım ve Orman Müdürlüğü, Bulanık/Muş \\ ${ }^{2}$ Tokat Gaziosmanpaşa Üniversitesi, Ziraat Fakültesi, Toprak Bilimi ve Bitki Besleme, 60250, Tokat
}

\section{Öz}

Toprak bozulması, toprağın fiziksel, kimyasal ve biyolojik özelliklerinin toprağın üretim potansiyelini azaltacak şekilde değişmesi olayıdır. Toprak bozulmasının görüldüğü alanlarda arazilerin sürdürülebilirliği zorlaşmakta, toprakların erozyona duyarlılığının artması sonucu toprak kayıplarında artışlar olmaktadır. Bu çalışma TokatArtova ilçesi Çelikli Beldesi sınırlarında 10,412 $\mathrm{km}^{2}$ alana sahip su toplama havzasında gerçekleştirilmiştir. Çalışma iki dönemi kapsamaktadır. İlk çalışma 2001 yılı, ikinci çalışma ise 2012 yılında gerçekleştirilmiştir. Toprak bozulmasını belirlemek için havza topraklarında agregat stabilitesi, tekstür, kaymak bağlama eğilimi, hacim ağırlığı, sıkışma, iskelet yüzdesi, fosfor, potasyum, katyon değişim kapasitesi (KDK), organik madde, kireç içeriği ve $\mathrm{pH}$ değerleri incelenmiştir. Mera alanlarından dönemsel olarak alınan ot örnekleri ile kuru ot verimi, otlatma kapasitesi ve hayvan başına düşen mera alanları karşılaştırılmıștı. Aradan geçen on bir yıllık süreçte havza topraklarının kum, kil, silt içeriklerinde, iskelet yüzdesi, pH, KDK, organik madde, potasyum içeriklerinde istatistiksel olarak anlamlı bulunabilecek değişim belirlenmemiştir. Havza topraklarının fosfor içeriklerinde artış belirlenmiştir. Kaymak bağlama eğiliminde dönemsel olarak bir farklılık tespit edilememiş ve havza topraklarının kaymak bağlama eğilimleri çok düşük bulunmuştur. İkinci dönem çalışması sonucu havza alanının \%72,22'sinde toprakların agregat stabilitelerinin \%50'den az olduğu ve havzanın $0,992 \mathrm{~km}^{2}$ 'lik alanında toprak sıkışması olduğu tespit edilmiştir. Mera alanlarının kuru ot verimleri ve otlatma kapasitesinin azaldığı bunun sonucunda da hayvan başına düşen gerekli mera alanlarının arttığı belirlenmiştir. Havza alanının USLE eşitliği yardımı ile toprak kaybı miktarları hesaplanarak karşılaştırılmıştır. Havzada oluşan toprak kaybı miktarı 2001 yılı çalışması için ortalama 3,55 ton ha-1 $\mathrm{yll}^{-1}, 2012$ çalışması için toprak kaybı miktarı 5,68 ton ha ${ }^{-1} \mathrm{yl}^{-1}$ olarak belirlenmiştir.

Anahtar Kelimeler: Çölleşme, toprak bozulması, çölleşmenin izlenmesi, havza, Tokat.

\section{Determination of The Spatial and Temporal Soil Degradation Changes in Çelikli Pond Basin}

\begin{abstract}
Soil degradation refers to physical, chemical and biological changes in soil that adversely impact its production potential. It is difficult land sustainability where soil degradation is seen, as there is an increase in soil loss due to increased soil erodibility. This study has been conducted in catchment area of $10,412 \mathrm{~km}^{2}$ of Çelikli Village, which is part of Tokat-Artova district. The study was performed in covers 2 periods; first in 2001 and second in 2012. To determine soil degradation, aggregate stability, texture, soil crusting index, bulk density, penetration, coarse material, phosphorus, potassium, cation exchange capacity (CEC), organic material, lime contents and $\mathrm{pH}$ values were identified. Grass samples were collected periodically to compare dry grass yield, grazing capacity and grassland allocation per animal. It was not detected significantly statistical variation between 2001 and 2012 in terms of some characteristics such as contents of sand, clay and silt, coarse material, $\mathrm{pH}, \mathrm{CEC}$, organic material and potassium values. However, it was identified that the phosphorus values changed in the basin soil during this period. Soil crusting tendency did not show differ between the periods and it had been found to be very low. As a result of second period analysis, it has seen that $72,22 \%$ of basin has a value of soil aggregate stability lower than $50 \%$ and has soil penetration in $0,992 \mathrm{~km}^{2}$ of basin area. It has been seen that the grass yield and grazing capacity reduced, resulting in an increase in the required grassland allocation per animal. Basin soil loss was calculated and compared by using USLE equation. Soil loss amounts of the basin for 2001 and 2012 was average 3,55 tha ${ }^{-1}$ year $^{-1}$ and 5,68 tha ${ }^{-1}$ year $^{-1}$ respectively.
\end{abstract}

Keywords: Desertification, soil degradation, desertification monitoring, catchment, Tokat. 


\section{Giriş}

Kurak bölgeler dünya topraklarının yaklaşık \%41 kadar bir alanını kaplamakta olup, 2 milyar civarında insanın geçimini sağlar (Middleton vd., 2011). Dünya kurak alanlarının \%10-20'si toprak bozulmasına maruz kalmıştır (Anonymous, 2005). Toprak bozulması, genellikle tarım, mera veya yerleşim alanlarını kapsayan, toprakların yanlış kullanımından kaynaklanan fiziksel, kimyasal ve biyolojik bozulmayı içeren toprak kalitesindeki düşüş olup sadece toprak özellikleri, topografya ve iklim özellikleri dahil olmak üzere toprağın farklı fiziksel, kimyasal ve biyolojik faktörlerinin etkileşimine bağlı olmayıp, aynı zamanda toprak yönetimi ve arazi kullanımına da bağlıdır (Brevik vd., 2015).

Toprak bozulması toprak enerjisinin kaybı ya da azalması olarak tanımlanabilir. Toprak fonksiyonları tamamen enerji üzerine dayalıdır. Bu nedenle toprak bozulmasına toprak fonksiyonlarında ya da kullanımlarındaki kayıp ya da azalma olarak bakılabilir. Bu bakış açısı, toprak bozulmasının sürdürülebilir tarımı imkânsız kılacağı ve toprak kalitesinde onarılamaz kayıplara yol açacağını açıklar. Diğer toprak yönetim uygulamalarının gereği gibi yapılması durumunda bile bozulmuş bir toprağın, oluşan enerji kaybından dolayı kendine yüklenen işlevleri tam olarak yerine getiremeyeceğini belirler (Lal vd., 1997).

Toprak kalitesindeki bozulma, birçok araştırmacı tarafından toprağın sahip olduğu fiziksel ve kimyasal özelliklerin değerlendirilmesiyle yapılmıştır (Paz-Ferreiro ve Fu, 2016). Uzun yıllar süresince gerçekleştirilen toprak işleme işlemleri, temelde toprak erozyonu kaynaklı toprak bozulmasına, toprak fiziksel özelliklerinde olumsuzluklara ve zayıf agregasyona yol açar. Zira erozyonla toprak ince fraksiyonları yıkanır ve geride kumlu bir tekstür bırakır (Lema vd., 2019). Yarı kurak alanlarda uygulanan entegre toprak ve su koruma uygulamalarının, toprağın fiziksel özelliklerini iyileştirmek için dikkate değer bir potansiyele sahip olduğu öne sürülmüştür (Mesfin vd., 2018a).

Kuzey Etiyopya'da yürütülen bir çalışmada uzun süredir işlemeli tarım yapılan alanların toprak fiziksel özellikleri değerlendirilmiştir. Eğim ve toprak haritalarının üst üste bindirilmesiyle belirlenen on iki Arazi Haritalama Birimi (LMU) dikkate alınarak on iki bozulmuş ve 12 bozulmamış toprak örneği toplanmış ve toprağın fiziksel özellikleri analiz edilmiştir. Toprak hacim ağırlı̆̆ LMU3'te 1,22 $\mathrm{g} \mathrm{cm}^{-3}$ 'ten LMU4'te 1,68 $\mathrm{g} \mathrm{cm}^{-3} \mathrm{e}^{\prime}$ kadar değişmiştir. Yarayışlı su kapasitesi LMU4'te 0,09 ile LMU3'te 0,17 arasında değişmiştir. Stabilite indeksi (SI) değerleri, LUM10'da 3,58'den LMU3'te 62,5'e kadar değişmiştir. En yüksek ve en düşük toprak kaymak bağlama eğilimi indeks değerleri, LMU5'te 1,53 ve LMU9'da 0,29 olarak bulunmuştur. Bu çalışma, hatalı toprak yönetimi uygulamalarının toprağın fiziksel bozulmasına neden olduğunu göstermiştir (Lema vd., 2019).

Toprak bozulmasını tanımlamak kadar zamansal değişimini izlemekte süreçte etkili unsurları ortaya koymak bakımından önemlidir. Bu amaçla, toprak bozulmasının havza düzeyinde izlendiği ve zamansal değişiminin bilimsel olarak ortaya konulduğu karşılaştırma alanlarına (benchmark site) ihtiyaç bulunmaktadır. Ülkemizde bu amaçla yeterli sayıda karşılaştırma sahası bulunmamaktadır. Bu çalışma ile bir su toplama havzasında (Tokat Artova Çelikli Gölet Havzası), mevcut toprak bozulması, sistematik olarak iki farklı dönem için (2001 ve 2012 yılları) tanımlanmış, karşılaştırılmış ve toprak bozulmasının zamansal değişimimi ortaya konulmaya çalışılmıştır.

\section{Materyal ve Metot}

\subsection{Materyal}

Araştırma, Tokat iline 35 km mesafede yer alan Çelikli Beldesi sınırlarında 1987 yılında inşa edilmiş Çelikli Göleti'nin su toplama havzasında yürütülmüştür. Çalışma alanının coğrafi konumu Şekil 1'de verilmiştir. Araştırmanın yürütüldüğü Çelikli Gölet Havzasının kuzeyinde Göçyolu, doğusunda Kurtlutepe, güneyinde Soğankayatepe, Boztepe ve batısında Avarekırantepe bulunmaktadır. Çelikli Gölet Havzası toplam 10,412 km² alan kaplamaktadır. Çelikli Havzası, İç Anadolu Bölgesi ile Karadeniz Bölgesi arasında yer almasından dolayı, yarı kurak karakterli geçit bölgesi iklimi özelliklerini taşımaktadır. Havzanın denizden yüksekliği 1.200-1.430 m olup, yukarı arazi fizyografik ünitesine sahiptir. Yörede ortalama yıllık yağ 1 ş 535,9 mm, ortalama sıcaklık 8, ${ }^{\circ} \mathrm{C}$ ve donlu gün sayısı 130,5 gündür (Karaş vd., 2017).

Çelikli Havzasında daha önceden seri düzeyinde yürütülen çalışmalara göre, Göçyolu, Yedikır, Kurtlutepeönü, Yayla, Yelten, Uluyol, Kevenli, Akardere ve Alıçlı serileri ayrımı yapılmıştır. Gölet havzasında ordo düzeyinde Entisol, Mollisol ve Alfisol topraklar tanımlanmış ve ayrımı yapılmıştır. Havza toprakları orta, dik ve çok dik meyilde olup, II, III, IV, VI, VII ve VIII. sınıf araziler bulunmaktadır. Havzada tarım, mera ve orman arazi kullanım türleri yer almaktadır. Tarım yapılan alanlarda ağırlıklı olarak buğday-nadas ekim nöbeti uygulanmakta, 
önemsiz miktarda mercimek ve yem bitkileri tarımı yapılmaktadır (Karaş vd., 2017).

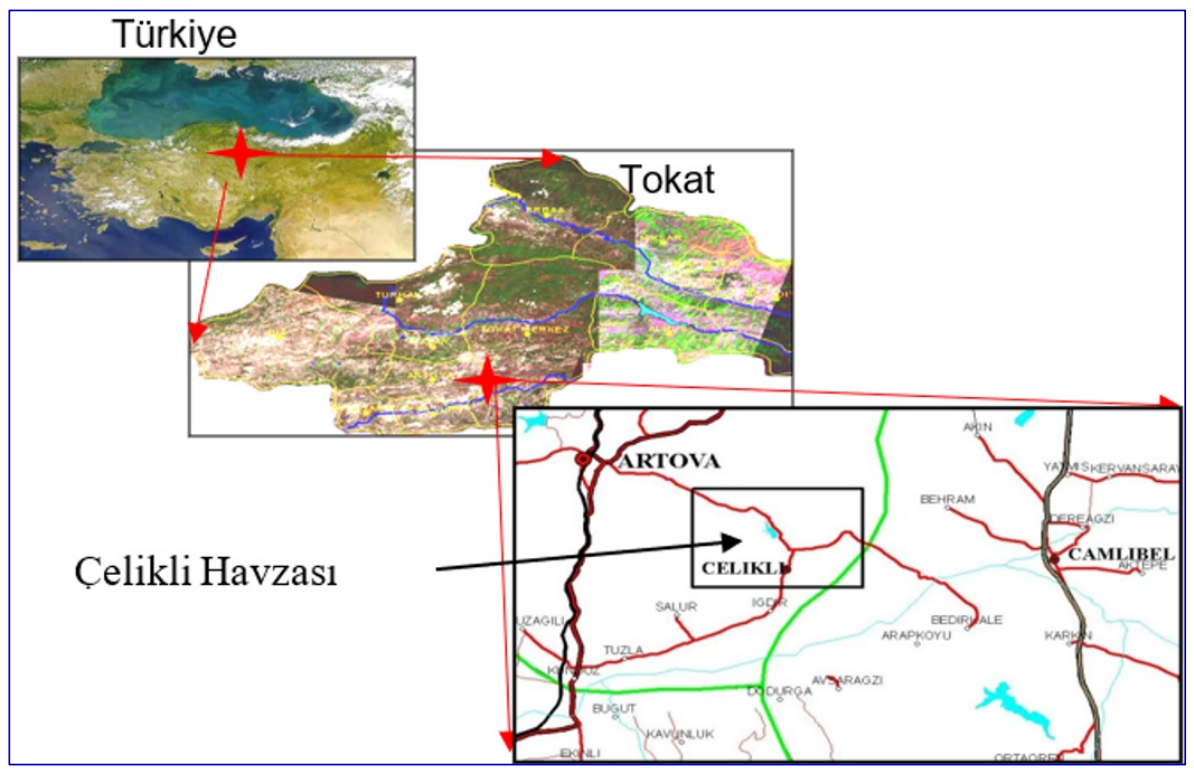

Şekil 1. Araştırma yeri yer buldur haritası.

\subsection{Metot}

\subsubsection{Havzada dönemsel toprak bozulma süreçlerinin belirlenmesi}

Çelikli Havzası topraklarının bozulma durumları birinci dönem (2001 yılı) ve ikinci dönem (2012 yılı) olacak şekilde 11 yıllık süreç için araştırılmıştır. Arazi çalışmaları ile elde edilen veriler, ArcGIS ortamında karşılıklı sorgulamalar ve istatistiksel analizlerle değerlendirilmiştir. Birinci dönem çalışmasında, üst topraktan 142, alt topraktan 115, ikinci dönem çalışmasında ise, üst ve alt toprak derinliklerinden 159 adet noktasal toprak örnekleri alınmıştır. Toprak örneklerinde yapılan analizler sonucu elde edilen noktasal veriler jeoistatistik yöntemler ile değerlendirilerek alansal verilere dönüştürülmüştür. Araştırmada toprak bozulması fiziksel, kimyasal ve biyolojik bozulma olmak üzere üç kısımda ele alınarak araştırılmıştır.

Havzada toprak bozulma durumunu ortaya koyabilmek amacıyla $\mathrm{pH}, \mathrm{EC}$, \% tuz, bazı besin element içerikleri $\left(\mathrm{P}_{2} \mathrm{O}_{5}, \mathrm{~K}_{2} \mathrm{O}\right)$, toplam kireç, organik madde, katyon değişim kapasitesi, hacim ağırlığı, tekstür, \% iskelet, agregat stabilitesi, kabuk bağlama eğilimi, potansiyel toprak kayıpları, mera alanlarının kuru ot verimi, otlatma kapasitesi, hayvan başına düşen mera alanı ve bazı erozyon eğilim indeksleri dikkate alınmıştır (Tüzüner, 1990). Toprakların kaymak bağlama özellikleri organik madde, kil ve silt içeriklerine göre tahmin edilmiştir. Bu amaçla çeşitli tahmin indekslerinden biri olan toprak organik madde oranı yaklaşımından yararlanılmıştır (Lal, 1988). Bu indekse göre;

$$
\text { S = Organik Madde İçeriği (\%) × } 100 \text { / (Kil (\%) + Silt (\%)) }
$$

Hacim ağırlığı silindir yöntemine göre, iskelet yüzdesi dispers olmuş 100 gr toprağın 2 mm çapındaki elekten elenmesi ve elek üstünde kalan materyalin toplam toprak ağırlığına oranlanması ile, agregat stabilitesi islak eleme yöntemine göre, tekstür Bouyoucos Hidrometre yöntemine göre belirlenmiştir (Tüzüner, 1990).

Havzaya ait toprak kayıpları Üniversal Toprak Kayıp Eşitliği (USLE) (Wishmeier ve Smith, 1978) yöntemine göre potansiyel yüzey ve parmak erozyonu olarak belirlenmiştir. USLE yöntemine göre potansiyel toprak kayıpları aşağıdaki eşitliğe göre hesaplanmaktadır:

$$
\mathrm{A}=\mathrm{R} \times \mathrm{K} \times \mathrm{L} \times \mathrm{S} \times \mathrm{C} \times \mathrm{P}
$$

Eşitlikte; A: Yıllık ortalama toprak kaybı (ton ha-1), R: Yağış erozyon indeksi (MJ mm ha ${ }^{-1} \mathrm{~h}^{-1} \mathrm{y}^{-1}$ ), K: Toprak erodibilite faktörü (Mg ha h ha-1 $\left.\mathrm{MJ}^{-1} \mathrm{~mm}^{-1}\right)$, L: Eğim uzunluğu faktörü, S: Eğim dikliği faktörü, C: Bitki yönetim faktörü, P: Toprak koruma önlemi faktörü olarak değerlendirilmektedir.

Yağış faktörü küçük havzalarda kolaylıkla değişmeyen bir etken olduğu için havzanın tamamında R değeri olarak 
Tokat ili için belirlenen 54,68 MJ mm ha-1 $\mathrm{h}^{-1} \mathrm{y}^{-1}(\mathrm{Oğuz}, 1997)$ değeri kullanılmıştır. K Faktör değeri ise aşağıdaki eşitlikten yararlanılarak her çalışma noktası için belirlenerek alansal haritalara dönüştürülmüştür (Wischmeier ve Smith, 1978).

$$
K=\left(\left(2,17 \times 10^{-4}\right) \times\left(M^{1,14}\right) \times(12-a)+3,25 \times(b-2)+2,5 \times(c-3)\right) \times d
$$

Eşitlikte; K: Toprak aşınım faktörü, M: Zerre irilik parametresi, a: Organik madde içeriği, \%, b: Strüktür tipi kodu, c: Su geçirgenliği kodu, d: Metrik sisteme dönüştürme katsayısıdır (d=1,292)

Eşitlikte yer alan zerre irilik (M) parametresi aşağıdaki eşitlik yardımıyla belirlenmiştir.

$$
\mathrm{M}=(\text { Çok ince kum }+ \text { Silt })(100-\text { Kil })
$$

Eşitlikte yer alan, strüktür kodunun belirlenmesi için gerekli strüktür belirlemesi çalışması arazide yapılmıștır. Eğim uzunluğu faktörü havzanın Sayısal Yükseklik Model (DEM) haritasından yararlanılarak Eşitlik 5 yardımıyla hesaplanmıştır.

$$
L=\left(\frac{l}{22.1}\right)^{m}
$$

Eşitlikte; L: Eğim uzunluğu faktörü, l: Eğim uzunluğu, m, m: Katsayı olup, eğim \%4’den büyükse 0,5, \%4 eğim için 0,4, \%3 ve daha az eğim için 0,3 olarak alınmıştır.

Eğim derecesi (S faktörü) faktörü Eşitlik 6 yardımıyla belirlenmiştir.

$$
S=\frac{0.43+(0.30 \times s)+\left(0.043 \times s^{2}\right)}{6.574}
$$

Eşitlikte; S: Eğim dikliği faktörü, s: Arazi eğimi, \%’dir.

C faktörünün havzadaki değerlerinin belirlenmesinde Tokat yöresinde yürütülen USLE faktörlerinin belirlenmesi çalışmasından (Oğuz, 1997) ve Çanga (1995)'de verilen değerlerden yararlanılmış ve havzada tarım, orman, mera, çıplak kaya ve su yüzeyi gibi arazi kullanım türleri için $\mathrm{C}$ faktörü değerleri belirlenmiştir.

Toprak kaybı toleransı toprağın bitki yetiştirilmesine ait köklenme derinlikleri dikkate alınarak 2,2 $\mathrm{t} \mathrm{ha}^{-1} \mathrm{y}^{-1} \mathrm{ile}^{-1}$ $11,2 \mathrm{t} \mathrm{ha}^{-1} \mathrm{yll}^{-1}$ arasındaki değerlerden seçilmiştir.

Mera arazilerinde verimi ve otlatma kapasitesini belirlemek amacıyla 16 adet örnekleme noktasında çalışma yapılmıştır. Bitki örnekleri temmuz ayında, otlar $1-2 \mathrm{~cm}$ yükseklikten biçilerek alınmış ve $65^{\circ} \mathrm{C}$ 'de sabit ağırlığa gelinceye kadar etüvde bekletilmiştir. Etüvden çıkarılan kuru ot örneği soğutularak tartılmış ve verim $\mathrm{kg} \mathrm{da}^{-1}$ olarak belirlenmiştir. Havza meralarının örtülülük durumları arazide gerçekleştirilen quadrat ölçümleri ile belirlenmiştir.

Otlatma kapasitesi ve hayvan başına düşen mera miktarı Eşitlik 7 ve Eşitlik 8 yardımıyla hesaplanmıştır (Anonim, 1998).

$$
\begin{aligned}
\text { Otlatma kapasitesi }= & \text { Meranın genişliği }(\mathrm{da}) \text { x yararlanılabilir kuru ot }(\mathrm{kg}) \\
& \text { verimi } / \text { Bir hayvanın günlük ot ihtiyacı }(\mathrm{kg}) \times \text { otlatma } \\
& \text { günü sayısı }
\end{aligned}
$$

Araştırma yeri için Hayvanın günlük ot ihtiyacı = Bir büyükbaş hayvanın (BBHB) günlük ot ihtiyacı 10 kg olarak alınmıştır. Otlatma Gün Sayısı = 182 gün olarak hesaplanmıştır.

$$
\begin{aligned}
\text { Hayvan başına düşen mera }= & \text { Otlatma gün sayısı }(\text { gün }) \times \text { Bir hayvanın günlük } \\
& \text { ot ihtiyacı }(\mathrm{kg}) / \text { yararlanılabilir kuru ot }(\mathrm{kg}) \\
& \text { verimi }(\text { Yılmaz, 1977) } .
\end{aligned}
$$

Yararlanılabilir yem miktarı $\left(\mathrm{kg} \mathrm{da}^{-1}\right)=$ Mera kuru ot veriminin \%50'si olarak kabul edilmiştir. 


\subsubsection{Havzanın sürdürülebilir yönetiminin planlanması}

Çelikli Havzası erozyon haritasının hazırlanması sonucu, elde edilen toprak kayıp bulguları dikkate alınarak erozyonu kontrol altına alacak önlemleri içeren havzanın sürdürülebilir kullanım planlaması yapılmıştır. $\mathrm{Bu}$ amaçla öncelikle mevcut toprak kayıplarına karşı gerekli önlemleri ortaya koyabilmek amacıyla SLUP (Sürdürülebilir Arazi Kullanım) modelinden yararlanılmıştır (Karaş ve Oğuz, 2015). Modelin esası, mevcut potansiyel toprak kayıplarının (A), toprak kayıp tolerans değerlerine ( $T$ ) oranlanması ve elde edilen $A / T$ değerine göre bir havzanın gerekli önlemler paketinin ortaya konulmasına dayanmaktadır. Belirlenmiş olan A/T oranlarına göre bir havza için önerilen önlemler paketi Tablo 1'de verilmiş̧ir. Çelikli Havzası toprak koruma önlemleri Tablo 1'e göre her iki dönem için olacak şekilde ortaya konulmuştur.

Tablo 1. Sürdürülebilir Arazi Kullanım Modeli (SLUP) toprak koruma önlem seviyeleri (Karaş ve Oğuz, 2015).

\begin{tabular}{|c|c|c|c|}
\hline $\begin{array}{l}\text { Önlem } \\
\text { Derecesi }\end{array}$ & $\begin{array}{l}\text { Toprak Kayıplarının } \\
\text { (A) Tolerans (T) } \\
\text { Değerine oranı (A/T) }\end{array}$ & $\begin{array}{l}\text { Erozyon } \\
\text { Tanımı }\end{array}$ & Uygulanacak Toprak Koruma Önlemi \\
\hline 1 & $\leq 1,0 \mathrm{~T}$ & Yok veya az & $\begin{array}{l}\text { Kültürel önlemler (tarım alanlarında ekim nöbeti, uygun toprak işleme, } \\
\text { gübreleme, meralarda kontrollü otlatma) }\end{array}$ \\
\hline 2 & $1,1 \mathrm{~T}-2,0 \mathrm{~T}$ & Düşük - orta & $\begin{array}{l}\text { Kültürel önlemler (1. derecedeki uygulamalara ilaveten tarım alanlarında tesviye } \\
\text { eğrilerine paralel tarım, meralarda örtü geliştirme) }\end{array}$ \\
\hline 3 & $2,0 \mathrm{~T}-4,0 \mathrm{~T}$ & Orta- yüksek & $\begin{array}{l}\text { Kültürel tedbirler + Fiziksel yapılar (2. derecedeki uygulamalara ilaveten tarım } \\
\text { alanlarında tesviye eğrilerine paralel şeritvari tarım, drenaj, teraslama, meralarda } \\
\text { örtü geliştirme, orman alanlarında teras veya karıklar) }\end{array}$ \\
\hline 4 & $4,0 \mathrm{~T}-6,0 \mathrm{~T}$ & Yüksek & Arazi kullanım türünde değişiklik (otlak, mera veya ormana dönüşüm) \\
\hline 5 & $>6,0 \mathrm{~T}$ & Şiddetli & $\begin{array}{l}\text { Arazi kullanım türü değişikliği + Fiziksel yapılar (kademeli stabilizasyon } \\
\text { yapıları, akarsu yatak ıslahı, otlandırılmış su yolları, fildöper inşaası vb) }\end{array}$ \\
\hline
\end{tabular}

\subsection{3. İstatistiksel analizler}

Çelikli Havzası toprak örneklerinin noktasal verilerinin alansal verilere dönüşümünde, Arcview yazılımın jeoistatistik analiz fonksiyonundan yararlanılmıştır (ESRI, 2011). Türetilen alansal veriye ilişkin histograma bakılarak verilerin normal dağılıma uyup uymadığı kontrol edilmiş, normal dağılımı bozan uç değerler çıkartılmıştır. Histogram ve QQPlot değerlendirmesi sonucu Ordinary ve Simple kriging yöntemi kullanılmıştır. Gaussian, spherical ve exponantial semivariogram modellerinden en yakın dağılımı gösteren model dikkate alınmış, aynı veri için hangi kriging yönteminin RMS değeri sıfır (0)'a yakın, RMSS değeri bir (1)'e yakın ise haritalama amacıyla o yöntem seçilmiştir.

\section{Bulgular ve Tartışma}

\subsection{Fiziksel bozulma}

Kötü fiziksel kaliteye sahip topraklar, düşük infiltrasyon oranlarına, yüksek yüzey akışa, düşük havalanmaya, zayıf bitki köklenmesine ve sert toprak işlenebilirliğine sahiptir (Dexter, 2004). Çelikli Havzası topraklarının fiziksel bozulma unsurları, erozyon, tekstürel fraksiyonlarda değişim, agregat stabilitesi, hacim ağırlı̆̆ı, toprak sıkışması, iskelet yüzdesi ve kaymak bağlama eğilimi değerleri dikkate alınarak iki dönem için tanımlanmıştır. Zira hacim ağırlığı, tekstür, elverişli su kapasitesi agregat stabilitesi ve kaymak bağlama gibi önemli toprak fiziksel özellikleri, genellikle toprak fiziksel kalitesi için temsili göstergeler olarak önerilmektedir (Boix-Fayos vd., 2001).

Havzanın potansiyel toprak kayıpları Üniversal Toprak Kaybı Eşitliği (USLE) ile hesaplanmıştır. Yağışın erozyon oluşturma gücü ( $\mathrm{R}$ faktörü), Tokat ili için belirlenen 54,68 ton-m ha ${ }^{-1}$ (Oğuz, 1997) değeri, her iki araştırma dönemi için olmak üzere kullanılmışıı. Toprak analizleri ve aşınıma duyarlılık eşitliği yardımıyla belirlenmiş ve alansal veri haline getirilmiş harita bulgularına göre, birinci dönem ve ikinci dönem K Faktör değerleri sırasıyla 0,5-0,14 ve 0,11-0,33 olmuştur. Çelikli Havzasının bitki yönetim faktör (C) değerlerinin belirlenmesinde Tokat yöresinde yürütülen USLE parsel çalışması bulgularından (Oğuz, 1997) ve Çanga (1995) tarafından verilen literatür verilerinden yararlanılmıştır. Havzada kullanılan C faktörü değerleri Buğday-Nadas münavebesi için 0,25, Orman alanları için 0,038 ve Mera alanları için 0,05 olarak seçilmiştir. Havzada herhangi bir toprak koruma yöntemi uygulanmadığından toprak koruma faktörü (P) değeri 1,0 olarak alınmıştır. Çelikli Havzasının eğim uzunluğu ve dikliği faktör (LS) değerleri DEM hesaplamaları sonucuna göre 0 - 29,927 arasında değişmiştir. 
Üniversal denklemi oluşturan faktör değerlerinin Arcview ortamında matematiksel çarpımı sonucunda çalışma havzasının potansiyel toprak kayıpları hesaplanmıştır (Şekil 2). Birinci dönem çalışması sonucuna göre Çelikli Havzasında toprak kayıpları 0-129,3 $\mathrm{t} \mathrm{ha}^{-1} \mathrm{y}_{1} \mathrm{l}^{-1}$, ikinci dönem çalışmasına göre ise 0-175,76 tha-1 $\mathrm{y}_{1} \mathrm{l}^{-1}$ arasında değişmiştir. Birinci dönem ortalama havza toprak kaybı 3,55 $\mathrm{t} \mathrm{ha}^{-1} \mathrm{y}_{1} \mathrm{l}^{-1}$, ikinci dönem ortalama havza toprak kaybı ise 5,68 t ha ${ }^{-1} \mathrm{y}_{1}{ }^{-1}$ olarak hesaplanmıştır. Çalışma bulgularına göre, ikinci dönem çalışması sonucu toprak kayıplarında meydana gelen artış dikkat çekmektedir. Havza topraklarında tanımlanan fiziksel, kimyasal, biyolojik bozulma unsurlarının ve toprak işlemeli tarımın yapılmasının toprağın aşınıma duyarlılık değerlerinde artışa yol açmıştır. Havzanın oldukça eğimli yapıda olması ve aşınıma duyarlılığının artması, yağış ve yüzey akışın etkisini arttırmakta ve sonucunda da erozyon ile toprak kayıplarının artmasına neden olduğu görülmektedir.

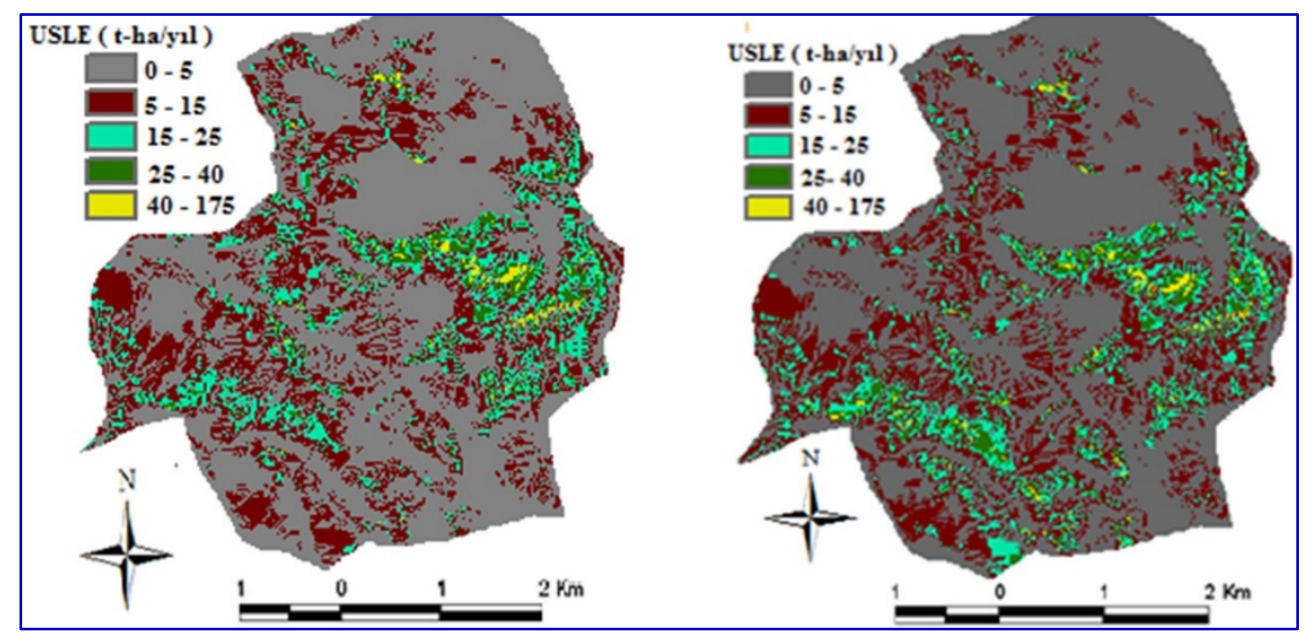

Şekil 2. Çelikli havzası 2001 ve 2012 yılları toprak kayıplarının karşılaştırılması.

Çelikli Havzası için erozyon kontrol ihtiyacı, sayısal olarak SLUP model yardımıyla belirlenmiştir (Tablo 2). SLUP model de önerildiği üzere kullanılan A/T oranlarına göre havzada her iki dönemde de toplam beş önlem derecesi belirlenmiştir. İki dönem için önlem dereceleri karşılaştırıldığında, 1. Önlem derecesinde alansal bir artış, 2. ve 3. erozyon derecelerinde azalma, 4. ve 5. erozyon derecelerinde ise artış görülmüştür. Bu sonuca göre, ikinci dönem çalışması ilk dönem bulguları ile karşıllaştırılacak olursa, yüksek risk taşıan alanlarda (4. ve 5. derece) alansal artış eğiliminin dikkate alınması, gerekli fiziksel önlemler ve arazi kullanım türü değişikliklerinin uygulamaya geçirilmesi sürdürülebilirlik bakımından gerekmektedir.

Tablo 2. Erozyon derecesinin her iki dönem çalışmasına ait alansal dağılımı.

\begin{tabular}{lllllll}
\hline $\begin{array}{l}\text { Önlem } \\
\text { Derecesi }\end{array}$ & A/T & Erozyon Sinıfi & $\mathbf{2 0 0 2}$ & \multicolumn{2}{c}{$\mathbf{2 0 1 2}$} & \\
\cline { 3 - 6 } & & & $\begin{array}{l}\text { Alan } \\
\mathbf{k m}^{2}\end{array}$ & $\mathbf{\%}$ & $\mathbf{k m}^{\mathbf{2}}$ & $\mathbf{\%}$ \\
\hline 1 & $0-1$ & Yok veya az & 6,140 & 59,04 & 6,270 & 60,26 \\
2 & $1-2$ & Düşük-orta & 2,820 & 27,16 & 2,630 & 25,26 \\
3 & $2-4$ & Orta-yüksek & 1,070 & 10,35 & 1,000 & 9,61 \\
4 & $4-6$ & Yüksek & 0,300 & 2,92 & 0,422 & 4,06 \\
5 & $>6$ & Şiddetli & 0,055 & 0,53 & 0,084 & 0,81 \\
Toplam & & & $\mathbf{1 0 , 4 1 2}$ & $\mathbf{1 0 0 , 0 0}$ & $\mathbf{1 0 , 4 1 2}$ & $\mathbf{1 0 0 , 0 0}$ \\
\hline
\end{tabular}

A: potansiyel toprak kaybı, ton $m \mathrm{ha}^{-1}$, $\mathrm{T}$ : toprak kaybı tolerans değeri $\mathrm{t} m \mathrm{ma}^{-1}$.

Havza topraklarının tekstürel fraksiyonlarının alansal yayılımı her iki dönem için karşılaştırılmıştır. Havza topraklarının kum fraksiyonlarında iki dönem arasında önemli bir değişim gözlemlenmemiştir. Ancak yüzey akışa bağlı olarak toprakların aşınması, taşıması ve birikmesi olayları sonucu kısa mesafelerde oransal olarak önemli olmayan birtakım değişimler olmuştur. Bununla birlikte kum içeriklerindeki ikinci dönem görülen bir miktar artış eğilimi, istatistiksel olarak anlamlı bulunmamıştır. Genellikle yüksek intensiteli yağışlar toprağın kum fraksiyonunun taşınmasında etkin rol oynarken daha düşük intensiteli yağışlar, daha küçük boyutta olan kil ve silt içeriklerinin taşınmasında daha etkindir. Erozyon sahalarında en çok görülen olaylardan biri de kil minerallerinin hareketinin fazla olmasıdır. Havzada genel olarak dönemsel üst ve alt toprak horizonlarının kil içeriklerinde önemli bir değişiklik belirlenmemiştir. Üst ve alt toprak horizonlarının ortalama kil içeriklerinin birinci dönem çalışmasına oranla azalması istatistiksel olarak anlamlı bulunmamıştır. Kil oranlarındaki azalma, erozyonla aşınan toprağın yüzey akışla taşınmasının bir sonucu olarak düşünülmektedir. Bu durum sürüm, ekim ve dikim 
gibi geleneksel insan faaliyetleri sonucunda hızlandırılmış erozyona bağlı fiziksel bozulma unsurunun bir sonucu olabilir. Geleneksel çiftlik uygulamalarını kullanarak sürekli ekim faaliyetleri, toprak kalitesinin bozulmasına ve düşük arazi verimliliğine yol açmaktadır (Cammeraat ve Imeson, 1998). Kil içeriğinin azalması, buna karşı kum içeriğinde görülen artma eğilimi havza topraklarında olası agregasyon ve agregat stabilitesinde azalma şeklinde kendini gösterecektir. Çelikli havzası topraklarının silt içeriklerinde de diğer tekstürel fraksiyonlarda olduğu gibi her iki dönem için önemli bir farklılık görülmemiştir.

Toprakların strüktürel dayanımlarının erozyonu azaltan, su hareketlerini kolaylaştıran ve bitki kök gelişimini olumlu olarak etkilemelerinden dolayı, agregatların yağmur ve sulama suyuna dayanıklı olmaları istenir. İnce kum içeriklerine sahip zayıf agregatlı topraklar, ekili arazilerin yüzey toprağını yağmur damlası etkisine karşı daha duyarlı hale getirmektedir (Buhmann, vd., 2006). Bu amaçla çalışma alanı toprakları için ikinci dönem çalışmasına ait üst ve alt toprak katmanlarının agregat dayanımları <\%50 ve \%50-100 olmak üzere iki gruba ayrılmıştır. Havza üst toprak agregat dayanımlarının \%72,22’si <\%50 ve \%27,78’i \%50-100 arasında olmuştur. \%50 agregasyon oldukça düşük bir agregasyon oranı olup, havza topraklarının fiziksel özelliklerini geliştirici önlemlerinin alınması gerekmektedir. Alt toprağın agregat dayanımı üst toprağa göre daha iyi durumdadır. Bu sonuç, üst toprağın otlatma ve tarımsal faaliyetlere maruz kalmasından dolayı agregat yapılarının zamanla bozulduğunu göstermektedir. Bayer et al. 2001, toprak işleme yoğunluğundaki artışın, toprak organik maddesinin hızlı bir şekilde kaybolmasına, düşük biyolojik aktiviteye ve agregat stabilitesinde azalmaya neden olduğunu belirtmişlerdir.

Topraklarda tarla içi trafik, aşırı otlatma gibi nedenlerden kaynaklanan toprak sıkışması sonucu toprağın penetrasyon direnci ve hacim ağırlığı değerlerinde artışlar olurken, toplam gözeneklilik, boşluk oranı, havalanma ve drenaj gözeneklerinin oransal olarak azalmasına neden olur. Bunun sonucunda fazla su toprağın derinliklerine sızamaz ve yüzey akışa geçerek erozyona neden olur. Bu amaç doğrultusunda Çelikli havzası topraklarının birinci dönem çalışması üst ve alt toprak penetrasyon direnci, ikinci dönem çalışmasında ise üst ve alt toprak hacim ağırlıklarının değerleri incelenmiştir. Yapılan birinci dönem çalışması sonucu Çelikli havzasının toprak sıkışma dağılımını belirlemek amacıyla koni toprak penetrometresi ile üst ve alt toprak katmanlarının sıkışma değerleri belirlenmiştir. Ürün verimini olumsuz etkileyecek sıkışma değeri sabit bir değer olmayıp, toprakların sahip olduğu özelliklerine göre değişmektedir. Nitekim yapılan bir araştırma sonucuna göre, 2.000 kpascal değeri altında sıkışma sorunu bulunmamakta, ancak 2.000 kpascal üzerindeki sıkışma değerleri ürün verimini etkilediği bildirilmektedir (Taylor vd., 1966). Başka araştırmacılar ise $3 \mathrm{Mpa}$ değerini aşan sıkışma değerlerinin ürün verimini etkilediğini bildirmektedirler (Gerard vd., 1982; Vepraskas ve Miner, 1986; Vepraskas ve Wagger, 1989). Çelikli Havzası üst toprakları alansal olarak \%34,92'de 2 Mpa üzerinde sıkışma değeri göstermiştir. Alt toprağın tamamına yakınının sıkışma değeri 2 Mpa üzerinde olmuştur. Yüzey sıkışma ortalama değeri 1.671,22 Kpascal, alt toprağın ise 2.579,63 Kpascal olarak belirlenmiştir. Havza mera alanlarında 0-20 cm derinlikte sı̆̆ topraklardan ibaret oluşları nedeniyle yalnızca yüzey sıkışması değerleri belirlenmiştir. Üst toprak sıkışma değerlerinin değişim katsayısı ve standart sapma değerleri toprak işleme süreçlerinin etkisinden dolayı alt toprağa göre daha fazla olmuştur. İkinci çalışma dönemi verilerine göre, havza topraklarının üst ve alt toprak hacim ağırlıkları çoğunlukla 1,2-1,3 $\mathrm{gr} \mathrm{cm}^{-3}$ arasında bulunmuştur. Topraklar bünyelerine göre hacim ağırlıklarını 1,3$1,6 \mathrm{gr} \mathrm{cm}^{-3}$ aralığında değişmesi beklenir. Toprak hacim ağırlığının kritik değerinin; killi topraklar için 1,5-1,6 gr $\mathrm{cm}^{-3}$, tınlı ve kumlu topraklar için 1,6-1,8 $\mathrm{gr} \mathrm{cm}^{-3}$ olduğu bildirilmiştir (Veihmeyer ve Hendrickson 1948). Bununla birlikte, tarım topraklarında tavsiye edilen hacim ağırlığı değeri; toprak tipi, tekstürü ve mineral madde içeriğine bağlı olarak 1,1-1,4 gr cm ${ }^{-3}$, değerleri arasında olması gerekmektedir (Craul, 1999). Kumlu topraklar daha az boşluk içermelerinden dolayı killi topraklara göre daha yüksek hacim ağırlığı değerleri verirler. Topraklarda 1,6 $\mathrm{gr} \mathrm{cm}^{-3}$ 'ün üstündeki hacim ağırlı̆̆ı değeri sıkışmanın olduğunu göstermektedir. $1,3 \mathrm{gr}^{\mathrm{cm}} \mathrm{cm}^{-3}$ değerinin altındaki değerler ise hacim ağırlığının azaldığını, gözeneklilik miktarının arttığını göstermektedir. İkinci dönem havza topraklarının toprak katmanlarına göre hacim ağırlık değerleri 1,29-1,31 gr $\mathrm{cm}^{-3}$ arasında değişmiştir. 1,5-1,9 $\mathrm{gr} \mathrm{cm}^{-3}$ değer aralığına sahip 0,992 $\mathrm{km}^{2}$ ’lik bir alanda alt toprakta hacim ağırlığında artışa bağlı olarak toprak sıkışma riski olduğu belirlenmiştir. Alt toprakta meydana gelen sıkışma, tarım alanlarında yürütülen tarımsal faaliyetlerin bir sonucu olduğu düşünülmektedir.

Erozyona maruz yüzeylerde en belirgin özelliklerden birisi de toprağın erozyona hassas olan kısımlarının kolayca taşınması sonucunda, toprak içerisindeki $2 \mathrm{~mm}$ 'den büyük zerrelerin yani toprak iskeletinin oransal miktarının artmasıdır. Bu amaçla Çelikli Havzası topraklarının iskelet içerikleri birinci ve ikinci araştırma dönemlerini kapsayacak şekilde incelenmiştir. Havza topraklarının iskelet içerikleri <\%15, \%15-20 ve \%> 20 olmak üzere üst ve alt toprak katmanları için karşılaştırılmıştır. Havza topraklarının iskelet içerikleri alansal olarak, ilk dönemde çoğunlukla \%15-20 arasında, ikinci dönemde ise <\%15 olmuştur. Alt toprakta ise, her iki dönem için de iskelet içeriği ağırlıklı olarak \%15-20 arasında değişmiştir. Alansal iskelet içerik bulguları, iki dönemde olarak değerlendirildiğinde, anlamlı bir yorumlamayı mümkün kılamamıştır. Erozyona konu olan üst toprağın yanı sıra alt toprak katmanlarında da iskelet içeriğinin oldukça yüksek olması havzada toprak kalınlığının yetersizliği de 
dikkate alınacak olursa mevcut iskelet kapsamı, erozyonun etkisi yanı sıra, toprak özelliklerini oluşturan ana materyalin sürüm gibi işlemlerle üst toprağa karışması ve diğer pedogenetik işlemlerin sonucu olarak değiştiği düşünülmektedir. Üst toprak iskelet içeriğinde görülen dalgalanmaların bir nedeni olarak, bir taraftan aşınma süreçleriyle ince materyalin taşındığı dolayısıyla iskelet içeriğinin arttığı, diğer tarafta ise, aşınan ince materyalin havza içinde birikerek iskelet içeriğinde azalmaya yol açmış olduğu düşünülmektedir.

Çelikli Havzası topraklarının kaymak bağlama eğilimi her iki dönem için Eşitlik 1'den yararlanılarak üst topraklar için belirlenmiştir. Her iki dönem için oluşturulan alansal haritaların karşılaştırılması sonucuna göre, havza topraklarının kaymak bağlama eğiliminde dikkati çeken dönemsel farklılıklar görülmemiştir. Her iki dönem için de üst toprakların kaymak bağlama eğilimleri çok düşük bulunmuştur. Toprağın sürekli işlenmesinin toprak yapısını tahrip edebileceğini ve toprağı yağmur damlası etkisine maruz bırakarak kabuklaşmaya neden olabileceğini bildirilmiştir (Mills vd., 2006). Araştırma yerinde nadaslı kuru tarım uygulaması toprak işleme uygulamalarına daha az maruz kalması kaymak bağlama eğiliminin düşük düzeyde kalmasına neden olduğu düşünülmektedir. Havza genelinde her iki dönem çalışmaları sonucu toprakların organik madde miktarlarının az olması ve kil + silt miktarlarında önemli bir değişikliğin olmaması dönemsel değişimin olmamasına neden olmuştur.

\subsection{Kimyasal bozulma}

Dönemsel olarak belirlenen üst ve alt toprak katmanlarının pH içerikleri karşılaştırılmıştır. Birinci dönem üst toprak $\mathrm{pH}$ değerleri 6,37-8,63 arasında, ikinci dönem $\mathrm{pH}$ değerleri ise 6,11-8,21 arasında değişmiştir. Birinci dönem alt toprak pH değerleri 6.37-8.30, ikinci dönem ise 6,26-8,49 değerleri arasında değişmiş̧ir. Her iki dönem üst ve alt toprak örneklerinin $\mathrm{pH}$ değerlerinde herhangi anlamlı bir değişim belirlenmemiştir. Havza alanının yaklaşık \%60'ının nötr $(6,5-7,5)$ pH aralığında kaldığı, hafif asidik $(6,11-6,37)$ ve kuvvetli alkali $(<8,63)$ özellik gösteren topraklar havza alanının çok küçük bir kısmını oluşturmuş̧tur. Dönemsel olarak üst ve alt toprak pH değerlerinde görülen azalmalar istatistiksel olarak anlamlı bulunmamıştır.

Çelikli havzası üst ve alt toprak horizonlarının organik madde içerikleri her iki dönem için çoğunlukla \%1-2 (az) olarak belirlenmiştir. Birinci dönem üst toprak organik madde içeriği \%0,41-4,33, ikinci dönem \%0,06-4,24 arasında değişmiştir. Birinci dönem alt toprak organik madde içeriği \%0,14-2,32, ikinci dönem ise \%0,06-3,48 arasında değişmiştir. Üst ve alt toprak horizonlarının organik madde içeriklerinin değişim katsayılarında ve ortalama değerlerinde önemli bir değişiklik olmamış, standart sapma değerleri ise düşük bulunmuştur. Üst ve alt toprak organik madde içeriğinde meydana gelen oransal farklılıklar havza alanının çok az kısmında gerçekleşmiş ve istatistiksel olarak anlamlı bulunmamıştır. Uzun süre tarımsal amaçlarla kullanılan topraklar, sık ekim, düşük bitki örtüsü ve yüksek toprak sıkışması nedeniyle düşük toprak organik madde içeriğgine sahiptir (Reynolds ve Topp, 2008). Çelikli Havzası tarım arazilerinde benzer şekilde yapılan yanlış uygulamalar ve meralarda bilinçsizce yapılan hayvan otlatma uygulamaları sonucunda organik madde miktarlarının azaldığı düşünülmektedir.

Çelikli Havzası topraklarının çok az bir bölümü kireç taşı ana materyali üzerinde gelişmiştir. Bu sebeple üst toprak kireç içeriği \%1,94-\%47,14, alt toprak kireç içeriği ise \%1,55-\%50,7 arasında değişmiştir. Fazla ve çok fazla sınıfında kireç içeriğine sahip alanlar ana materyali kalker olan topraklardır ve alansal dağılımları havza geneline göre oldukça az bulunmuştur. Topraklarda kireç içeriğinin yüksek olması fosfor, demir, mangan, çinko gibi besin elementlerinin alınımını olumsuz yönde etkilemesi ve toprak pH'sının yükselmesine neden olduğu için toprak verimliliğinin azalmasına yol açmaktadır. Bu nedenlerden dolayı tarım yapılan topraklarda istenmezler. Tarım ve mera alanlarının çok az bir kısmında toprakların kireç içeriklerinin çok yüksek olduğu belirlenmiştir.

Havza topraklarının ilk dönem üst toprak katyon değişim kapasitesi 17,63-67,04 cmol kg-1 , ikinci çalışma üst toprak KDK ise 7,65-86,66 cmol kg${ }^{-1}$ arasında değişmiştir. Her iki dönem üst toprak KDK'ları çoğunlukla 30-40 $\mathrm{cmol} \mathrm{kg}^{-1}$ arasında değişmiştir. Çalışma sonucu elde edilen bulgulara göre havza genelinin KDK içeriğinde önemli bir değişikliğin olmadığı belirlenmiştir. Havza topraklarının dönemsel olarak organik madde içeriklerinin az bulunması ve kil içeriklerinde önemli bir değişikliğin olmaması durumu KDK değerlerinin değişmemesine neden olduğu gözlemlenmiştir. Havza içerisinde meydana gelen önemsiz alansal farklılıklar, tarımsal faaliyetler ve erozyon gibi etkilerle kil minerallerinin taşınmasından kaynaklandığı düşünülmektedir. İki döneme ait üst toprak KDK değerlerinin değişim katsayıları düşük bulunmuş, ortalama KDK değerlerin de ise önemli bir farklılık bulunmamıştır. Havza geneli KDK ortalama 34,17- 34,73 meq/100 gr arasında değişmiştir.

Havza topraklarının dönemsel olarak $\mathrm{K}_{2} \mathrm{O}$ içerikleri karşılaşıtırılmış ve her iki dönem için havza topraklarının potasyum içeriklerinde önemli bir değişikliğin olmadığı ve bitki besleme bakımından yeterli düzeyde olduğu belirlenmiştir. İkinci dönem üst ve alt toprak potasyum ortalama miktarlarında meydana gelen artma eğilimi 
istatistiksel olarak anlamlı bulunmamıştır. Havza topraklarının kil içeriklerinde dönemsel bir değişimin olmaması, toprakların potasyum içeriklerinin de değişmemesine etki ettiği söylenebilir. Bitkisel üretim için 50 $\mathrm{kg} \mathrm{da}^{-1} \mathrm{~K}_{2} \mathrm{O}$ içeriği yeterlidir ve bu durumda havza için yeterli potasyum kapsamının mevcut olduğu söylenebilir. Havza topraklarının fosfor kapsamları birinci ve ikinci dönemi kapsayacak şekilde incelenmiştir. Birinci dönem çalışmasına göre üst toprak fosfor içeriğinin çoğunlukla 1-3 kg da-1 (çok az), alt toprak fosfor içeriğinin ise 3-6 $\mathrm{kg} \mathrm{da}^{-1}$ (az) olduğu belirlenmiştir. İkinci dönem çalışmasına göre üst toprakta 9-15 kg da ${ }^{-1}$ (çok yüksek), alt toprakta ise 6-9 $\mathrm{kg} \mathrm{da}^{-1}$ (orta) düzeyde fosfor içeriğinin olduğu görülmektedir. Elde edilen bulgulara göre her iki dönem çalışması için toprakların fosfor içeriklerinde ve alansal olarak dağılımlarında anlamlı bir farklılık söz konusudur ve fosfor içeriğindeki artış istatistiksel olarak önemli bulunmuştur. Birinci dönem ile ikinci dönem toprak katmanlarının fosfor içeriklerinin değișim katsayıları düşük olmuştur. İkinci çalışma sonucu toprakların fosfor içeriğindeki artış; tarım arazilerinde fosforlu gübre uygulamalarının arttığını göstermektedir. Yapılan görüşmeler sonucu çiftçiler tarafından her yıl toprağa fosforlu gübre uygulamalarının yapıldığı öğrenilmiştir. Fosfor içeriğindeki bu artışın, ekim ile birlikte toprağa gereğinden fazla fosfor uygulamalarının sonucu olarak toprakta birikim göstermesine bağlanmıştır. Toprakta fazla bulunan fosfor yüzey suları ile taşınarak ötrofikasyona neden olur. Ötrofikasyon sonucu suların kalitesi düşmektedir. Havza içerisinde bulunan sulama göleti, toprak fosfor içeriğinde görülen bu artış nedeniyle ötrofikasyon tehlikesi altındadır.

\subsection{Biyolojik bozulma}

Çelikli Havzası biyolojik bozulma unsurlarını tanımlayabilmek için mera havza mera alanlarında arazi çalışmaları yapılmıştır. Bu amaçla, mera kuru ot verimi, mera otlatma kapasitesi ve hayvan başına düşen mera alanı verileri elde edilmiş ve dönemsel olarak karşılaştırılmıştır. Çelikli Belde halkının geçim kaynaklarından biri olan hayvancılık faaliyetleri nedeni ile havza içerisindeki mera alanlarının kuru ot verimi önem taşımaktadır. İlk dönem çalışma sonucuna göre mera kuru ot verimi 24-349 $\mathrm{kg} \mathrm{da}^{-1}$ arasında değişmiş, havza ortalama mera kuru ot verimi $124,75 \mathrm{~kg} \mathrm{da}^{-1}$ olarak hesaplanmıştır. İkinci dönem mera kuru ot verimleri 9,6-147 kg da-1 arasında değişmiş, ikinci dönem mera kuru ot verim ortalaması $69 \mathrm{~kg} / \mathrm{da}$ olarak tespit edilmiştir. Ülkemizde yapılan çalışmalarda kuru ot verimi ortalaması; Bakır (1963) tarafından $122 \mathrm{~kg} \mathrm{da}^{-1}$, Bakır (1970) tarafından 122,7 kg da1, Özmen (1977) tarafından 74,5 kg da ${ }^{-1}$, Gökkuş vd. (1993) tarafından $69 \mathrm{~kg} \mathrm{da}^{-1}$, Babalık ve Sönmez (2010) tarafından 80,26 kg da $\mathrm{kg}^{-1}$ olarak rapor edilmiştir. Çelikli havzası mera alanlarının kuru ot verimleri, yapılan çalışmalarda belirlenen kuru ot verimi değerleri arasında yer almaktadır. Çelikli havzası meraları \%2-30 eğimli yerlerde bulunmaktadır. Aşırı otlatma ve bunun sonucu toprakta meydana gelen sıkışmadan dolayı yağış sularının infiltrasyonu azalmakta ve eğimli bölgelerde sular yüzey akışa geçerek erozyona sebep olmaktadır. Yeterli nemin toprak tarafından tutulamaması, aşırı otlatma ve erozyon sebebi ile vejetasyon iyi gelişememekte dolayısı ile meraların ot verimi azalmaktadır. Son yıllarda etkisini iyice hissettiren kuraklık, toprakta yeterince nem tutulmaması nedeni ile kuru ot veriminde neredeyse yarı yarıya azalma meydana gelmiştir. Çelikli Havzası mera alanları $2.589 \mathrm{~km}^{2}$ alan kaplamakta olup havza toplam alanının \%24,86'sını oluşturmaktadır. Havzada otlatma dönemi nisan ayının ortalarında başlayıp ekim ayının ortalarına kadar devam etmektedir. Nadas döneminde hayvanlar tüm havza alanına yayılırken buğday ekili dönemlerde otlatma mevsimi başlangıcı olan nisan ayının ikinci yarısından itibaren temmuz ayının ilk yarısının sonuna kadar sadece merada ve buğday hasadından sonra ise tüm havzada yayılmaktadırlar. Artova ilçesinin meteorolojik verileri dikkate alınarak havzanın otlatma gün sayısı 182 gün olarak hesaplanmıştır (DMI, 2017). Havzada son derece kısıtlı olan mera alanlarında yaklaşık 3000 büyükbaş ve 2000 küçükbaş hayvan olmak üzere toplam 5000 hayvan otlatılmaktadır. Ağır otlatmadan dolayı vejetasyon yeterince gelişememekte özellikle sıkışma olmak üzere çeşitli toprak bozulma süreçlerinin de katkısıyla mera kuru ot verimi ve kalitesi gittikçe düşmektedir. Türkiye Mera Yönetmeliğine göre bir yerli inek 0,5 Büyükbaş Hayvan Birimi (BBHB) olarak kabul edilmektedir (Anonim, 1998). Aynı yönetmeliğe göre, bir koyun 0,10 BBHB olarak kabul edilmektedir. Bu durumda havzada otlayan hayvanların BBHB olarak karşılı̆̆ı; 3.000 Büyükbaş Hayvan × 0,5 = 1.500 BBHB ve 2.000 Küçükbaş Hayvan $\times 0,1=200$ BBHB olmak üzere tüm havza için toplam otlayan hayvan sayısı 1700 BBHB olarak hesaplanmıştır. Merada otlayan 1.700 BBHB tüm mera alanına bölündüğünde, 1 km² mera alanına 656,6 BBHB düştüğü hesaplanmıştır. Çelikli havzası yarı kurak iklim bölgesinde bulunmaktadır. Kurak ve yarı kurak bölge meraları için tavsiye edilen mera kuru ot veriminin \%50’si yararlanılabilir kuru ot olarak kabul edilmektedir (Tükel ve Hatipoğlu, 1997). Otlatma kapasitesi (OK) hesabında bu değer kullanılmıştır.

$$
\begin{aligned}
& \mathrm{OK}=2589 \times 62,37 / 10 \times 182=88,73 \mathrm{BBHB} \\
& \mathrm{OK}=2589 \times 34,50 / 10 \times 182=49,07 \mathrm{BBHB}
\end{aligned}
$$

Çelikli Havzası merası mevcut kuru ot verimi ve alanı dikkate alınırsa mera otlatma kapasitesi birinci dönem çalışması sonucu 88,73 BBHB olarak hesaplanmıştır. Yapılan ikinci dönem çalışması sonucu otlatma kapasitesi 49,07 BBHB olarak hesaplanmıştır. Havza içerisinde kalan meraların otlatma kapasitelerinin 11 yıllık süreçte 
neredeyse yarı yarıya azaldığı tespit edilmiştir. Çelikli Havzasında bir BBHB için birinci dönem çalışması bulgularına göre, 29,17 da mera alanına ihtiyaç var iken, ikinci dönem çalışması sonucuna göre 52,75 da meraya ihtiyaç duyulduğu belirlenmiştir. Havzadaki merada 1.700 BBHB bulunmaktadır. Çelikli Kasabasındaki tüm hayvanların yeterli ve dengeli beslenebilmeleri için mevcut mera kalitesinde $1.700 \times 52,75=89.675$ da mera alanına ihtiyaç vardır ki bu rakam mevcut mera alanının 34,63 katına eşittir. Meraların bilinçsizce kullanımı, ağır otlatma neticesinde vejetasyonun tahrip edilmesi sonucu meraların otlatma kapasitesi azalmış, kuru ot verimi düşmüştür. Mera alanlarının BBHB’nin dengeli beslenmelerini karşılayamadığı ve kalitesinin gittikçe düştüğü gözlemlenmiştir.

\section{Sonuç ve Öneriler}

Bu çalışmada Yeşilırmak Havzasında yer alan Çelikli Gölet'i su toplama havzasında toprak bozulma riski ve durumu iki dönem karşılaştırmalı olarak araştırılmıştır. Havzada bozulma unsurları fiziksel, kimyasal ve biyolojik toprak bozulması olarak ele alınmıştır. İlk arazi çalışmalarının yapıldığ 2001 yılından itibaren ikinci dönem arazi çalışmasının yürütüldüğü 2012 yılına kadar havzada çeşitli değişikliklerin meydana geldiği gözlemlenmiştir.

Fiziksel bozulma unsuru altında toprak kayıpları, bünyesel değişimler, agregat stabilitesi, sıkışma, hacim ağırlı̆̆ı, iskelet içeriği ve kaymak bağlama eğilimi olarak ele alınmıştır. Fiziksel bozulma unsurlarından su erozyonunun arazide arttığ ve alınması gerekli koruma önlemlerinin daha fazla maliyet gerektirir bir hale geldiği görülmüştür. Gölet'in sedimentle dolma riski artmıştır. Havza topraklarında önemli bulunacak bünyesel değişimler gözlemlenmemiştir. Havza topraklarında iskelet içeriğinde dikkati çeker değişimin olmaması, toprak işleme ile erozyon ve birikme süreçlerinin ortak etkisi olarak değerlendirilmiştir. Havza topraklarının önemli bir bölümünde agregat stabilitesi \%50'nin altında oluşu toprakların fiziksel bozucu güçlere karşı yeterli düzeyde direnci gösteremeyeceği ve toprakların erozyona daha duyarlı hale geldiği belirlenmiştir. Toprakların kaymak bağlama eğilimlerinde önemli risk ve dönemsel değişim görülmemiştir. Havzada alt topraklarda sıkışma sorunu bulunmakla birlikte hacim ağırlıkları normal değerlerde bulunmuştur. Toprak bozulma süreçlerinin etkileri sonucu havza genelinde erozyon ile toprak kaybı miktarlarında 2012 yılında yapılan çalışma ile artış tespit edilmiştir. Tarım arazilerinde işlemeli tarımın yapılması ve mera alanlarında aşırı otlatma sonucu toprakların aşınıma olan duyarlılıklarının artmasına neden olduğu ve sonucunda da toprak kaybı miktarlarının arttığı belirlenmiştir.

Havzada kimyasal bozulma unsurları olarak toprak reaksiyonu, organik madde, kireç, katyon değişim kapasitesi, potasyum ve fosfor içerikleri olarak incelenmiştir. Aradan geçen süreçte toprak reaksiyonunda, KDK kapsamında önemli bir değişim belirlenmemiştir. Organik madde içeriklerinde üst topraklarda hafif azalma, alt topraklarda ise hafif artma eğilimi belirlenmiştir. Potasyum içeriğinde, dönemsel olarak önemli bir değişim görülmemiş topraklarda yeterli düzeyde potasyum varlı̆ğ belirlenmiştir. Fosfor içeriklerinde artış belirlenmiştir. Fosfor içeriğinde görülen artış, havzada yer alan gölet üzerinde oluşturacağı ötrofikasyon riski ayrıca araştırılması gereken bir konudur. Aradan geçen süreçte gübre kullanımında bir artış olduğu ve uygulanan gübrelerden fosforun toprakta biriktiği anlaşılmıştır.

Biyolojik bozulma unsuru olarak meralardaki otlatma kapasitesi, kuru ot verimi hayvan başına düşen mera alanı olarak ele alınmıştır. Çalışma bulgusu olarak aradan geçen süreçte otlatma kapasitesi ve kuru ot verimi neredeyse yarıya yakın oranda azaldığı tespit edilmiştir. Bunun sonucu olarak da hayvan başına düşen mera alanı ihtiyacının arttı̆̆ 1 belirlenmiştir.

Havzada mera alanlarının bir kısmı ormana dönüştürülmüş olmakla birlikte asıl sorunun işlemeli tarım altında olan eğimli arazilerden kaynaklandığı dikkate alınmalıdır. Fiziksel bozulma unsurlarından su erozyonunun kontrol altına alınabilmesi için arazi kullanım planlarının yapılması yararlı olacaktır. Mevcut mera varlığı geliştirilmeye ve yönetilmeye ihtiyaç duymaktadır. Bu amaçla mera yönetim planlamaları yapılmalıdır. Havzada uygulanan özellikle fosforlu gübreler toprakta birikmeye başladığ1 ve gölette ötrofikasyon riski oluşturduğu düşünülmektedir. Göletler planlanırken aynı zamanda havzanın toprak bozulma unsurlarına karşı havzaların planlanması önerilmektedir. Mevcut sorunlar bu çalışma ışığında ele alınarak gölet havzası sürdürülebilir bir duruma getirilebilir. Ancak yapılacak sslah maliyeti sorunun daha da derinleşmesinden dolayı 2012 yılı değerlendirmelerine göre daha fazla olacaktır.

Yarı kurak alanlarda uygulanan entegre toprak ve su koruma önlemleri gibi toprak yönetim uygulamaları, toprağın fiziksel niteliklerini iyileştirmek için dikkate değer bir potansiyele sahip olduğu bildirilmiştir (Mesfin vd., 2018b). Kurak ve yarı kurak step vejetasyon koşullarında bir havzada sürdürülen bu çalışmanın gelecek dönemlerde başka araştırmacılar tarafından ele alınması ve sürekli izleme sistemi oluşturulması benzer havzalarda bozulma dirençlerinin dinamiğini izlemek ve toprak bozulmasını daha iyi anlamak bakımından önerilmektedir. 


\section{Destekleyen Kurum}

Bu çalışma Proje Numarası: 2012/116 olarak Tokat Gaziosmanpaşa Üniversitesi Bilimsel Araştırma Projeleri Koordinasyon birimince desteklenmiştir.

\section{Kaynaklar}

1. Anonim (1998). Türkiye mera yönetmeliği. Resmi Gazete 31.07 .1998 tarih ve 23419 say1.

2. Anonymous (2005). Ecosystems and Human Well-being World Health Organization, Millennium Ecosystem Assessment, Geneva, Switzerland.

3. Babalık, A.A., Sönmez, K. (2010). Isparta İli Bozanönü Köyü Kırtepe Merasında botanik kompozisyonun belirlenmesi üzerine bir araştırma, Bartın Orman Fakültesi Dergisi, Cilt: 12, Sayı: 17, s. 27-36.

4. Bakır, Ö. (1963). O.D.T.Ü arazisinde bir mera etüdü, A.Ü. Ziraat Fakültesi Yayınları No: 382, Ankara.

5. Bakır, Ö. (1970). Orta Doğu Teknik Üniversitesi Arazisinde Bir Mera Etüdü, A.Ü. Ziraat Fakültesi Yayınları No: 232, Ankara.

6. Bayer, C., Martin-Neto, L., Mielniczuk, J., Pillon, C.N., Sangoi, L. (2001). Changes in soil organic matter fractions under subtropical no-till cropping systems, Soil Science Society of America Journal, 65, 1473-1478.

7. Boix-Fayos, C., Calvo-Cases, A., Imeson, A. C. (2001). Influence of soil properties on the aggregation of some Mediterranean soils and the use of aggregate size and stability as land degradation indices. Catena, 44, $47-67$.

8. Brevik, E.C., Cerdà, A., Mataix-Solera, J., Pereg, L., Quinton, J.N., Six, J., Van Oost, K. (2015). The interdisciplinary nature of Soil. Soil, 1: 117-129.

9. Buhmann, C., Beukes, D. J., Turner, D.P. (2006). Clay mineral associations in soils of the Lusikisiki area, Eastern Cape and their agricultural significance, South African Journal of Plant and Soil, 23, 78 -86

10. Cammeraat, L. H., Imeson, A. (1998). Deriving indicators of soil degradation from soil aggregation studies in SE Spain and S France, Wageningen. Geomorphology, 23(2), 307-321.

11. Çanga, M.R. (1995). Toprak ve su koruma. Ankara Üniversitesi Ziraat Fakültesi yayınları, Yayın no: 1386, Ders kitab1: 400, 118 s., Ankara.

12. Chivenge, P. P., Murwira, H. K., Giller, K. E., Mapfumo, P., Six, J. (2007). Long-term impact of reduced tillage and residue management on soil carbon stabilization: Implications for conservation agriculture on contrasting soils. Soil and Tillage Research, 94, 328-337.

13. Craul, P.J. (1999). Urban Soils: Applications and Practices, Wiley, Toronto.

14. Dexter, A.R. (2004). Soil physical quality: I. Theory, effects of soil texture, density, and organic matter, and effects on root growth. Geoderma, 120(3-4), 201-214.

15. DMI (2017). Aksaray İli uzun yıllık meteorolojik verileri (Yazılı Görüşme).

16. ESRI (2011). Environmental Systems Research Institute, ArcGIS for Desktop, Version 10.1. - Redlands CD ROM.

17. Gerard, C.J., Sexton, P., Shaw, G. (1982). Physical factors influencing soil strength and root growth, Agronomy Journal, 74:875-879.

18. Gökkuş, A., Avcı, M., Aydın, A., Mermer, A., Ulutaş, Z. (1993). Yükseklik eğim ve yöneyin mera vejetasyonlarına etkileri, Tarım Orman Köyişleri Bakanlığı Doğu Anadolu Tarımsal Araştırma Enstitüsü Yayın no: 13, A.Ü. Ziraat Fakültesi Ofset Tesisi, Erzurum.

19. Karaş, E., Oğuz, E., Koçyiğit, R. (2017). Çelikli havzası arazisinin detaylı toprak etüt, haritalama ve sınıflandırılması, Anadolu Tarım Bilimleri Dergisi, 32:105-113.

20. Karaş, E., Oğuz, İ. (2015). A new approach to determine land use planning and soil conservation measures based on soil erosion classification, Carpathian Journal of Earth and Environmental Sciences, 10:2, 145158.

21. Lal, R. (1988). Soil erosion research methods, Soil and Water Conservation Society, Iowa, USA.

22. Lal, R., Blum, N.H., Valentine, C., Stewart, B.A. (1997). Methods for assesment of soil degredation. Advances in Soil Science. CRC press, New York.

23. Lema, B., Mesfin, S., Kebede, F., Abraha, Z., Fitiwy, I., Haileselassie, H. (2019). Evaluation of soil physical properties of long-used cultivated lands as a deriving indicator of soil degradation, north Ethiopia, Physical Geography, 40:4, 323-338.

24. Mesfin, S., Taye, G., Desta, Y., Sibhatu, B., Muruts, H., Mohammedbrhan, M. (2018b). Shortterm effects of bench terraces on selected soil physical and chemical properties: Landscape improvement for hillside farming in semi-arid areas of northern Ethiopia. Environmental Earth Sciences, 77, 390. 
25. Mesfin, S., Taye, G., Hailemariam, M. (2018a). Effects of integrated soil and water conservation measures on soil aggregate stability, soil organic matter and soil organic carbon stock of smallholder farmlands in semi-arid Northern Ethiopia. Carbon Management, 9,1-10.

26. Middleton, N., Stringer, L.C., Goudie, A., Thomas, D.S.G. (2011). The Forgotten Billion: MDG Achievement in the Drylands, UNCCD-UNDP, New York and Nairobi.

27. Mills, A.J., Fey, M.V., Gronkroft, A., Peterson, A., Medinski, T.V. (2006). Unravelling the effects of soil properties on water infiltration: Segmented quantile regression on a large data set from arid southwest Africa. Australian Journal of Soil Research, 44, 783-797.

28. Oğuz, İ. (1997). Tokat yöresinde koluviyal toprak grubunda üniversal denklemin $K, \mathrm{R}, \mathrm{C}$ ve $\mathrm{P}$ faktörleri. Köy Hizmetleri Genel Müdürlüğü, Araştırma Yıllığı 1996. Yayın No 102, 69-79, Ankara.

29. Özmen, T. (1977). Konya İli meralarının bitki örtüsü üzerinde araştırmalar, Doktora Tezi (Yayınlanmamış). A.Ü. Fen Bilimleri Enstitüsü. Ankara.

30. Paz-Ferreiro, J., Fu, S. (2016). Biological indices for soil quality evaluation: perspectives and limitations. Land Degradation, Development, 27, 14-25.

31. Reynolds, W. D., Topp, G. C. (2008). Soil Water. Analyses, Principles and Parameters. In M. R. Carter, E. G. Gregorich (Eds.), Soil Sampling and Methods of Analysis (pp. 1-198). Boca Raton: CRC Press, Taylor and Francis Group.

32. Taylor, H.M., Robertson, G.M., Parker, J.J. (1966). Soil strength-root penetration relations for medium to coarse -textured soil materials. Soil Science, 102:18-23.

33. Tükel, T., Hatipoglu, R. (1997). Çayır mera amenajmanı. Çukurova Üniversitesi. Ziraat. Fakültesi Ofset Atölyesi, s.152, Adana.

34. Tüzüner, A. (1990). Toprak ve su analiz el kitabı, Köy Hizmetleri Genel Müdürlüğü, Ankara.

35. Veihmeyer, F.J., Hendrickson, A.H. (1948). Soil density and root penetration, Soil Science, 65, 487- 494.

36. Vepraskas, M.J., Wagger, M.G. (1989). Cone index values diagnostic of where subsoiling can increase corn root growth, Soil Science Society of America Journal, 53:1499-1506.

37. Vepreskas, M.J., Miner, G.S. (1986). Effects of subsoiling and mechanical impedance on tobacco root growth in coarse-textured soils, Soil Science Society of America Journal, 50:423-427.

38. Wischmeier, W.H., Smith, D.D. (1978). Predicting rainfall erosion losses. Agricultural Handbook 537, USDA, 58 pp, Washington, D.C., USA.

39. Yılmaz, T. (1977). Konya İli sorun alanlarında oluşan meraların bitki örtüsü üzerinde araştırmalar. Konya B.T.A.E. Genel Yayın No: 46, Raporlar Serisi No: 32, Konya. 